\title{
Exposure to High Levels of Noise Poses Hazards and Risks for Development of Hypertension and Heart Disease: Potential Roles of Unrecognized Ionized Hypomagnesemia and Release of Ceramides and Platelet-Activating Factor
}

Burton M. Altura ${ }^{1-6}$, Asefa Gebrewold ${ }^{1}$, Anthony Carella ${ }^{1}$, Nilank C. Shah ${ }^{1,5}$, Bella T. Altura ${ }^{1,3-6}$

${ }^{1}$ Department of Physiology and Pharmacology, ${ }^{2}$ Department of Medicine,

${ }^{3}$ The Center for Cardiovascular and Muscle Research,

${ }^{4}$ The School for Graduate Studies in Molecular and Cellular Science, State University of New York Downstate Medical Center, Brooklyn, New York, USA, ${ }^{5}$ Bio-Defense Systems, Inc, Rockville Centre, New York, USA;

${ }^{6}$ The Magnesium for Health Foundation, Patterson, California burton.altura@downstate.edu

Abstract: It has been demonstrated in numerous human and animal studies that audiogenic stress (AS) can induce elevation of arterial blood pressure and cardiac damage and that noise -induced hearing loss may be associated with alterations in magnesium $(\mathrm{Mg}$ ) metabolism. Our laboratories, over a period of approximately 40 years, have been investigating why AS causes high blood pressure and cardiac damage. This review focuses on a number of newer discoveries on why AS causes dysfunctions of the cardiovascular system (CVS) This review discusses the pivotal physiological and biochemical importance of Mg to body health and the fact that most Americans and Europeans are deficient in daily Mg intake which perforce can cause severe dysfunctions of the CVS. Our ongoing studies clearly provide a solid microcirculatory basis for how and why AS above $65 \mathrm{~dB}(\mathrm{~A})$ often induces elevated blood pressure and cardiac damage. We review a body of data that points to the fact that AS does the latter, but appears to do so because noise stress levels result in Mg deficiency followed by release of certain sphingolipids (e.g., ceramides) and generation and release of platelet- activating factor (PDF). It is our opinion that all people exposed to high degrees of noise stress should be monitored for cardiovascular functions, ionized Mg levels, blood ceramide levels and levels of PDF. Lastly, we believe all people exposed to high levels of AS (i.e., maintenance people and pilots on aircraft carriers, musicians [particularly at rock concerts], motorman and conductors on trains and subways, construction site workers, etc.) should have at least the equivalent daily intake of 500-600 $\mathrm{mg}$ of $\mathrm{Mg} /$ day.

Keywords: microcirculation, blood pressure, cardiac function, sphingolipids, atherosclerosis, inflammation. In all industrialized societies, noise is an important environmental and occupational stress factor. There are several pathophysiological reactions to noise that range from hearing loss, annoyance, loss/lack of concentration to several dysfunctional alterations of the cardiovascular system; the latter leading to hypertension, heart attacks , and cardiac failure [1-5]. A high positive correlation has been found between exposure of individuals to noise and high blood pressure in a number of retrospective epidemiological studies [6-11]. Moreover, noise-induced elevation of arterial blood pressure in both rats and human subjects has been associated with increased peripheral vascular resistance and cardiac hypertrophy [10,12-16]. Although there is evidence of increased activation of the sympathetic nervous system with release of norepinephrine and epinephrine into the bloodstream during exposure to high levels of noise (i.e., above $85 \mathrm{~dB}(\mathrm{~A})$, the elevation in blood pressure, during noise exposure, is independent of elevated levels of catecholamines, cortisol, prolactin, or growth hormones [ 13-17 ]. In addition, central alpha ${ }_{2}$-adrenergic receptors do not appear to be involved [16]. 
Exposure to High Levels of Noise Poses Hazards and Risks for Development of Hypertension and Heart Disease: Potential Roles of Unrecognized Ionized Hypomagnesemia and Release of Ceramides and Platelet-Activating Factor

When one thinks about the risks and hazards of prolonged environmental noise exposure, most people only worry about loss of hearing. However, the unrecognized detrimental effects of excessive noise exposure, on the cardiovascular system is almost never thought of when patients present with hypertension and/or heart -coronary artery disease. This is particularly of great concern for navy pilots taking off from aircraft carriers and for the maintenance crews which work on the flight decks where noise levels usual range from 130-165 $\mathrm{dB}(\mathrm{A})$ [18 ]. In addition, in the civilian population, particularly our youth who attend rock concerts, the noise levels can be in excess of $165 \mathrm{~dB}$ )A) [4,5]. It should be pointed out that noise stress can produce reactions in the human body similar to stressors such as heat, cold, and shock caused by blood loss and trauma, or psychological causes such as heavy work -loads and intense anxiety/worry [2, 7,9,12,13,19]. How much of the high blood pressure and heart disease seen in the later years of navy pilots and teenagers, attending rock concerts, could be attributed, in part, to excessive environmental noise? What causes the cardiovascular dysfunctions observed in humans and animals exposed to prolonged and excessive noise levels?

\section{Noise-Induced Mg Deficits And High Blood Pressure}

A growing body of evidence is accumulating to suggest that there may be a "true" causal relationship between decreased magnesium (Mg) levels in the blood, tissues and cells after excessive noise exposure and development of hypertension $[10,11,19-23,59]$. It has been observed that the incidence of hypertension is often high in geographic regions with soft-drinking water or Mg-poor soil [24-33]. Hypomagnesemia has, indeed, been reported in a growing number of hypertensive subjects when the blood and tissues are examined for decreased levels of $\mathrm{Mg}[31,34]$. It has been demonstrated in a number of human and animal studies that oral and parenteral administration of $\mathrm{Mg}$ can often lower the elevated arterial blood pressures in subjects that present with high blood pressure[27,29-37 ]. Three of us have clearly shown that dietary deficiency of $\mathrm{Mg}$, under controlled laboratory conditions, will raise diastolic and systolic arterial blood pressures in a dose-dependent manner and aggravate hypertension in both spontaneously and deoxycorticosterone acetate -salt hypertensive rats; the less the dietary intake of $\mathrm{Mg}$, the higher the blood pressures up-to-a-point [10,32,35-40,60 ]. These findings have been confirmed by other investigators [41,42]. In numerous in-vivo and in-vitro studies, our group has found that reduced blood and tissue-cell levels of $\mathrm{Mg}^{2+}$ causes changes in cell geometry and cellular calcium overload, in all types of cells so far examined [10,29,33,34,37,40,43-58 ]. Such a series of events produces constriction/ vasospasm of all types of macro- and microscopic blood vessels [10,26,28,29,32-34,37-40,44,45,47-52, 53,54,57 ]. A microcirculatory basis for these important findings has been advanced by our group $[10,38,54,59,60]$. Exposure of laboratory animals to increasing levels of acoustical stress [e.g., from $65 \mathrm{~dB}(\mathrm{~A})$ to $100 \mathrm{~dB}(\mathrm{~A})$ ] over periods of from eight to 12 weeks for 12 hours daily results in reductions in serum Mg levels as well as deficits in cardiac and vascular smooth muscle $\mathrm{Mg}^{2+}$ levels in a dose-dependent manner; the longer the acoustical stress and the greater the levels of noise stress, the greater is the rise in systolic and diastolic blood pressures [10, 59, unpublished findings ]. Statistical analysis of these data demonstrate very high degrees of correlation between $\mathrm{Mg}^{2+}$ levels, degree of noise stress, and rise in arterial blood pressures (i.e., $\mathrm{P}<0.01$ ) .

\section{IMPORTANCE OF Mg TO Body HEALTH AND BiochemistRY}

$\mathrm{Mg}$ is a co-factor for more than 500 enzyme systems, and it is the second most abundant intracellular cation after potassium [61 ]. It is critical in numerous physiological, cellular and biochemical functions and systems, running the gamut from transmembrane fluxes of cations and anions, hormone-receptor binding, cellular energy generation, muscle contraction, nerve impulse conduction, regulation of DNA and RNA structure, regulation of carbohydrate, protein and lipid metabolism, regulation of plasma lipid levels(i.e., cholesterol, triglycerides, and LDL-cholesterol), regulation of cell and tissue growth, diverse cardiac functions and cardiac stability, regulation 
Exposure to High Levels of Noise Poses Hazards and Risks for Development of Hypertension and Heart Disease: Potential Roles of Unrecognized Ionized Hypomagnesemia and Release of Ceramides and Platelet-Activating Factor

of blood pressure, control of vasomotor tone and distribution of microcirculatory blood flows to all organ systems, and to cell death (e.g., apoptosis, necroptosis), among others [29,31,37,54,61,64 ]. Mg is depleted in most methods of food preparation (I.e., boiling, frying, etc.) and processing [60 ].

The daily intake of $\mathrm{Mg}$ has been declining since 1900, from where it was about 500-600 mg/day to about $150-235 \mathrm{mg} /$ day in many USA and European geographic regions at the present time [31, 34, 37, 60-67 ] Mg exists in three forms; free or ionized, complexed and protein-bound [36, 68 ]. These three forms constitute the total serum and cell $\mathrm{Mg}[36,68]$. Up to our extensive studies, there were no reliable methods to rapidly measure the ionized Mg fraction in blood and other body fluids, particularly in the OR and critical -coronary care units [36 ].

\section{Relationship of Mg to Cardiac Stabilization and Function, Hypertension and NOISE STRESS}

An increased risk for development of myocardial infarction and ischemic heart disease (IHD) has been clearly observed under long-term environmental noise stress [11-17,19-21]; the noise level usually has to be above $65 \mathrm{~dB}(\mathrm{~A})$ for these risks to become manifest. These levels of noise stress would be seen with road traffic noise, railroad noise, construction sites, subways, rock concerts, airports, and take-offs and landings from aircraft carriers [ 18,22,23]. All of these environmental stresses have been observed to be associated with deficits in Mg levels [5, 13,16,19,69].

Using normal, intact rats and perfused rat hearts, we have found that reduced dietary intake of $\mathrm{Mg}$ or reduced levels of $\mathrm{Mg}^{2+}$ in the perfusates, in isolated working rat hearts, caused numerous detrimental actions on the ability of the hearts to function properly [ 70-72 ]. For example, reduction in $\mathrm{Mg}^{2+}$ levels resulted in deficits in coronary blood flows, reductions in cardiac output, reductions in stroke volume and peak systolic pressure development, reductions in myocardial intracellular $\mathrm{Mg}^{2+}$ levels, reduction in myocardial levels of ATP, increased levels of inorganic phosphate, acidification of atrial and ventricular myocytes, $\mathrm{Ca}^{2+}$ overload, and generation of powerful reactive oxygen and nitrogen species (e.g., $\mathrm{H}_{2} \mathrm{O}_{2}$, hypochlorite anions, hydroxyl ions, ferrylmyoglobin, etc.) [70-72]. Acoustical stress (eg., in excess of $65 \mathrm{~dB}(\mathrm{~A})$ for eight to 12 weeks) resulted in similar pathophysiological effects on rat hearts as did Mg deficiency [ 72; unpublished findings].

However, when we examined the myocardiums and vascular smooth muscle cells exposed to Mg deficiency, or acoustical stress, we noted unique changes in sphingolipids and sphingolipid metabolism [33,34,73,84,88 ]. These studies led us into another series of biochemical and molecular pathways which have, we believe, direct bearing on the mechanisms whereby noise stress can lead to high blood pressure and cardiac-coronary artery disease.

\section{Mg2+ Regulates Sphingolipid Pathways in Cardiac and Vascular Smooth Muscle Cells: Relationship to EfFects in Noise STRESS}

Studies from our laboratories indicate that $\mathrm{Mg}^{2+}$ can modulate sphingolipid pathways in both cardiac and vascular smooth muscle (VSM) cells. A product of sphingolipid metabolism is ceramide and related lipids[74,75]. Ceramides are sphingolipids known to be released as a consequence of sphingomyelinases (SMases) acting on sphingomyelin (SM), a component of all extra- and intracellular cell membranes, or as a consequence of the activation of serine palmitoyl transferase 1 and 2(SPT 1 and SPT 2) (a de novo synthetic pathway). Ceramides are known to play important, and key, roles in fundamental pathophysiological processes such as inflammation, angiogenesis, atherogenesis, membrane-receptor functions, cell proliferation, microcirculatory functions, cell adhesion, immunogenic responses, excitation-contraction coupling events in cardiac and VSM cells, and cell 
Exposure to High Levels of Noise Poses Hazards and Risks for Development of Hypertension and Heart Disease: Potential Roles of Unrecognized Ionized Hypomagnesemia and Release of Ceramides and Platelet-Activating Factor

death (e.g., apoptosis, necroptosis) [74-79 ]. An upregulation of SPT 1 and SPT 2 has been hypothesized to play important roles in apoptosis and necroptosis events taking place in atherogenesis [80-81]. Such an upregulation could be quite pivotal in producing plaques on the endothelium of coronary arterial blood vessels leading to ischemic events, IHD, and myocardial infarctions. Our studies with cardiac muscle excised from rats exposed to acoustical stress [i.e., $65 \mathrm{~dB}(\mathrm{~A})$ to $100 \mathrm{~dB}(\mathrm{~A})$ ] for 8-12 weeks, $12 \mathrm{hr} /$ day, showed activation of SMases and formation of ceramides [73 ].

It is of considerable interest to note, here, that experimentally, myocardial infarctions have recently been found to be associated with rising levels of ceramides [81-83]. In human subjects, it has been reported that stable angina pectoris, unstable angina pectoris, and acute myocardial infarction are also associated with rising levels of ceramides [82, 83 ]. In some of these patients, a clear elevation in activation of SMases was observed along with a reduction in SM. .

During the performance of some of our experiments, with proton-nuclear magnetic spectroscopy, in vitro and in vivo with low $\left[\mathrm{Mg}^{2+}\right]_{0}$, we noted a rapid formation of a substance we identified as platelet-activating factor (PAF) along with PAF-like lipid molecules [84 ].

\section{Mg2+-Deficient Environments and Noise Stress Lead to Formation of Paf in Cardiac and Vsm Cells: Potential Significance to Noise-Stress -Induced Cardiac DYSFUNCTIONS AND HYPERTENSION}

PAF is known to be a major player in inflammatory responses, arterial blood pressure, and atherogenesis among many other physiologic functions [85-87 ]. In addition, PAF and PAF-like lipids are known to affect the heart and cardiac functions in numerous manners [ 85-87 ]. For example, PAF can produce coronary arterial vasoconstriction, alter arterial blood pressure, increase coronary vascular rersistance, release several lipid-like molecules from the heart, reduce cardiac output, decrease cardiac contractility, alter atrial and papillary chronotropicity and membrane potentials, as well as alter potassium currents in isolated cardiomyocytes [85-87 ]. All of these various attributes of PAF on the myocardium would be more than enough to cause profound atrial and ventricular fibrillation, IHD and myocardial infarctions. Moreover, a variety of the circulating blood-formed elements (e.g., leukocytes, platelets, basophils, and macrophages) can also elaborate PAF and PAF-like lipids, Recently, our group has reported that aortic, cerebral vascular and neonatal cardiac myocytes and coronary arterial VSM cells can also elaborate PAF , particularly when these cells are exposed to low $\left[\mathrm{Mg}^{2+}\right]_{0}$ levels [88 ]. Examination of microcirculatory blood vessels utilizing our TV image -intensification recording system with application/administration of PAF showed that this vasoactive lipid produced increased leukocytic adhesion on the endothelial walls, less rolling of leukocytes, and increased permeability of the postcapillary microvessel walls [88 ]; ceramides produced almost identical results [ 79 ]. We believe when these new data are viewed, in light of our other work, reviewed above, they could be used to advance the hypothesis that continued, acoustical stress-induced loss of tissue and cell $\mathrm{Mg}^{2+}$,over months and years, would lead to release of ceramides, PAF, and PAF-like lipids which could result in hypertension, cardiac ischemia followed by IHD, and myocardial infarction. If these pathophysiologic situations were coupled to dietary deficiency of $\mathrm{Mg}$, the effects on the cardiovascular system would be quite profound. Obviously, this hypothesis remains to be tested rigorously in human subjects. However, at the very least, we believe it would be propitious to supplement diets of human beings with enough $\mathrm{Mg}$ to cause a total intake of between 550-600 mg/day, particularly among subjects who are continually (i.e., daily for extended periods of time) subjected to high levels of acoustical stress. 
Exposure to High Levels of Noise Poses Hazards and Risks for Development of Hypertension and Heart Disease: Potential Roles of Unrecognized Ionized Hypomagnesemia and Release of Ceramides and Platelet-Activating Factor

\section{CONCLUSIONS AND FUTURE ThOUghtS}

Although the exact cause(s) of noise-induced hypertension, IHD and related myocardial infarctions is not known, $\mathrm{Mg}^{2+}$-depletion is clearly observed in experimental animals and humans exposed to noise levels in excess of $65 \mathrm{~dB}(\mathrm{~A})$ for prolonged periods of time. The greater the degree of acoustical stress, and the longer the time for exposure, the greater the loss of serum and tissue $\mathrm{Mg}$, at least in experimental animals. Generation/ release of sphingolipids (particularly ceramides), PAF and PAF-like lipids appear to be critically involved in the cardiovascular effects of prolonged acoustical stress, at least in experimental animals. These molecules should be looked for in humans exposed to road traffic noise, construction-site noises (e.g., particularly with prolonged use of jack-hammers), motorman and conductors on trains and subways, airports, and expecially pilots and maintenance crews on aircraft carriers. In order to test our hypothesis, animals and clinical trials on human subjects, exposed to the latter environmental changes, should be administered in some studies : 1 . Inhibitors of SMases and SPT 1 and 2; 2. receptor blockers of PAF on cardiac and VSM muscle cells; 3. exposure to the latter and former together; and 4. supplementation with orally-administered Mg compounds. We also believe all human subjects that present with high blood pressure and/or IHD and myocardial infarctions should be routinely tested for blood levels of ionized $\mathrm{Mg}$, as the latter is the physiologically-active form of $\mathrm{Mg}$, not total serum $\operatorname{Mg}[36,68]$.

\section{ACKNOWLEDGEMENTS}

The authors are indebted to the N.I.H.(NHLBI and NIAAA awarded to BMA \& BTA) for support for some of the original studies cited in the above.

\section{REFERENCES}

1. Martin RH, Gibson ES, Lockington JN (1975) Occupational hearing loss between 85 and 90 DBA. J Occup Med 17: 13-18.

2. Keyter KD (1979) The Effects of Noise on Man. Academic Press, New York.

3. Gloag D (1980) Noise: hearing loss and psychological effects. Br Med J 281: 1325-1327.

4. Ising H, Braun C (2000) Acute and chronic endocrine effects of noise: review of the research conducted at the Institute for Water, Soil and Air Hygiene. Noise \& Health 7: 7-24.

5. Anonymous (2008) Non-Auditory Effects of Noise. ICBEN 2008, $9^{\text {th }}$ International Congress on Noise as a Public Health Problem, Foxwoods, CT p 263-301.

6. Jonsson A, Hansson L (1977) Prolonged exposure to a stressful stimulus (noise) as a cause of raised blood pressure in man. Lance 1: 86-87.

7. Knipschild P (1977) Medical effects of aircraft noise : community cardiovascular survey. Int Arch Occup Environm Health 40: 185-204.

8. Mosskov JJ, Ettema JM (1977) Extra-auditory effects in long-term exposure to aircraft and traffic noise. Int Arch Environm Health 40: 177-184.

9. Cohen S, Krantz DS, Evans GW, Stokols D (1980) Cardiovascular and behavioral effects of community noise. Am Sci 69: 528-535.

10. Altura BM, Altura BT, Gebrewold A, Ising H, Gunther T (1992) Noise-induced hypertension and magnesium in rats: relationship to microcirculation and calcium. J Appl Physiol 72(1): 194-202. 
Exposure to High Levels of Noise Poses Hazards and Risks for Development of Hypertension and Heart Disease: Potential Roles of Unrecognized Ionized Hypomagnesemia and Release of Ceramides and Platelet-Activating Factor

11. Ising H, Kruppa B (2008) Animal studies. In: Night Noise Guidelines (NNGL) for Europe, Final Implementation Report. European Centre for Environment and Health, p151-160.

12. Rosecrans JA, Watzman N, Bukley JP (1966) The production of hypertension in male albino rats subjected to experimental stress. Biochem Pharmacol 15: 1707-1718.

13. Andren L (1982) Cardiovascular effects of noise. Acta Med Scand Suppl 657: 1-45

14. Andren L, Lindstedt G, Bjorkman M, Borg KO, Hansson L (1982) Effect of noise on blood pressure and "stress" hormones. Clin Sci London 62: 137-141.

15. Andren L, Hansson L, Eggertsen R, Hedner T, Karlberg BE (1983) Circulatory effects of noise. Acta Med Scand 213: 31-35.

16. Eggertsen R, Svensson A, Magnusson M, Andren L (1987) Hemodynamic effects of loud noise before and after central nervous stimulation. Acta Med Scand 221: 159-164.

17. McMann SM, Rothballer AB, Yeakel EH, Shenkin HA (1948) Adrenalectomy and blood pressure of rats subjected to auditory stimulation. Am J Physiol 155: 128-131.

18. Yong JS-e, Wang D-Y (2015) Impact of noise on hearing in the military. Military Med Res 2:6 D01 10.1186/ s40779-015-0034-5

19. Ising H, Dienel D, Gunther T, Markert B (1980) Health effects of traffic noise. Int Arch Occup Envitonm Health 47: 179-190.

20. Ising H, Gunther T, Handdrock M, Michalak R, Schwartz J, et al. (1981) Magnesium und Larmwirkungen . Magnesium Bull 3: 155-164.

21. Ising H, Handdrock M, Gunther T, Fischer R, Dombrowski M (1982) Increased noise trauma in guinea pigs through magnesium deficiency. Arch Otorhinolargynol 236: 139-146.

22. Joachims A, Ising H, Gunther T (1987) Noise-induced hearing loss in humans as a function of serum Mg concentration. Magnesium Bull 9:130-131.

23. Gunther T, Ising H, Joachims Z (1989) Biochemical mechanisms affecting susceptibility to noise-induced hearing loss. Am J Otol 10: 36-41.

24. Crawford T, Crawford MD (1967) Prevalence and pathological changes in ischemic heart disease in hard-water and in soft-water areas. Lancet 1: 229-232.

25. Anderson TW, Le Riche WH, Mckay JS, et al (1969) Sudden death and ischemic heart disease. Correlation with hardness of local water supply. N Engl J Med 280: 805-807.

26. Altura BM (1979) Sudden-death ischemic heart disease and dietary magnesium intake: is the target site coronary vascular smooth muscle? Med Hypoth 5: 843-849.

27. Dyckner T, Wester PO (1981) Effect of magnesium on blood pressure. Br Med J 286: 1842-1849.

28. Altura BM, Altura BT (1984) Interactions of Mg and K on blood vessels ----aspects in view of hypertension: review of present status and new findings. Magnesium 3: 175-194.

29. Altura BM, Altura BT (1984) Magnesium, electrolyte transport and coronary vascular tone . Drugs 28 (Suppl) : 120-142.

30. Marier JH, Neri LC (1985) Quantifying the role of magnesium in the interrelationship between human mortality/morbidity and water hardness. Magnesium 4: 53-59. 
Exposure to High Levels of Noise Poses Hazards and Risks for Development of Hypertension and Heart Disease: Potential Roles of Unrecognized Ionized Hypomagnesemia and Release of Ceramides and Platelet-Activating Factor

31. Altura BM, Altura BT (1985) New perspectives on the role of magnesium in pathophysiology of the cardiovascular system. Magnesium 4:226-244.

32. Altura BM, Altura BT (1991-1992) Cardiovascular risk factors and magnesium : relationships to atherosclerosis, ischemic heart disease and hypertension. Magnes Trace Elem 10: 182-192.

33. Altura BM, Altura BT (1995) Magnesium and cardiovascular biology: an important link between cardiovascular risk factors and atherogenesis. Cell Mol Biol Res 41: 347-359.

34. Altura BM, Altura BT (2007) Magnesium: forgotten mineral in cardiovascular biology. In: New Perspectives in Magnesium Research. Springer, New York, p 239-260.

35. Dean C (2017) The Magnesium Miracle, $4^{\text {th }}$ edn. Ballantine Books, New York.

36. Altura BM, Altura BT (2016) Importance of ionized magnesium measurements in physiology and medicine and the need for ion-selective electrodes. J Clin Case Studies 1: 1-4.

37. Altura BM, Altura BT (1995) Role of magnesium in the pathogenesis of hypertension updated: Relationship to its actions on cardiac, vascular smooth muscle, endothelial cells. In: Hypertension: Pathophysiology, Diagnosis, and Management, $2^{\text {nd }}$ edn. Laragh JH, Brenner BM, eds. Raven Press, New York, p 1213-1242.

38. Altura BM, Altura BT, Gebrewold A, Ising H, Gunther T (1984) Magnesium deficiency and hypertension: correlation between magnesium deficient diets and microcirculatory changes in situ. Science 223: 1315-1317.

39. Altura BT, Altura BM (1987) Cardiovascular actions of magnesium: Importance in etiology and treatment of high blood pressure. Magnesium Bull 9: 6-21.

40. Altura BM, Altura BT (1993) Magnesium, hypertensive vascular diseases, atherogenesis, subcellular compartmentation of $\mathrm{Ca}^{2+}$ and $\mathrm{Mg}^{2+}$, and vascular contractility. Mineral Electrolyte Metab 19: 323-336.

41. Berthelot A, Esposito J (1983) Effects of dietary magnesium on the development of hypertension in the spontaneously hypertensive rat. J Am Coll Nutr 4: 343-353.

42. Luthringer C, Rayssiguier Y, Gueux E, Berthelot A (1988) Effect of moderate magnesium deficiency on serum lipids, blood pressure and cardiovascular reactivity in normotensive rats. Br J Nutr 59: 243-250.

43. Altura BM, Altura BT (1971) Influence of magnesium on drug-induced contractions and ion content in rabbit aorta. Am J Physiol 220: 938-944.

44. Altura BM, Altura BT (1974) Magnesium and contraction of arterial smooth muscle. Microvasc Res 7: 145-155.

45. Altura BM, Altura BT (1978) Magnesium and vascular tone and reactivity. Blood Vessels 15: 5-16.

46. Turlapaty PDMV, Altura BM (1978) Extracellular magnesium ions control calcium exchange and content of vascular smooth muscle. Eur J Pharmacol 52: 421-423.

47. Altura BM, Altura BT (1981) Role of magnesium ions in contractility of blood vessels and skeletal muscles. Magnesium Bull 3: 102-114.

48. Altura BM, Altura BT (1981) Magnesium ions and contraction of vascular smooth muscles: Relationship to some vascular diseases. Federation Proc 40: 2672-2679.

49. Turlapaty PDMV, Weiner R, Altura BM (1981) Interactions of magnesium and verapamil on tone and contractility of vascular smooth muscle. Eur J Pharmacol 74: 263-272. 
Exposure to High Levels of Noise Poses Hazards and Risks for Development of Hypertension and Heart Disease: Potential Roles of Unrecognized Ionized Hypomagnesemia and Release of Ceramides and Platelet-Activating Factor

50. Altura BM, Altura BT, Carella A, Turlapaty PDMV (1982) $\mathrm{Ca}^{2+}$ coupling in vascular smooth muscle: $\mathrm{Mg}^{2+}$ and buffer effects on contractility and membrane $\mathrm{Ca}^{2+}$ movements. Canad J Physiol Pharmacol 60: 459- 482.

51. Altura BM, Altura BT (1981) Magnesium modulates calcium entry and contractility in vascular smooth muscle. In: Mechanisms of Gated Calcium Transport Across Biological Membranes, Ohnishi ST, Endo M, eds. Academic Press, New York , p 137-145.

52. Altura BM, Altura BT, Carella A (1983) Magnesium deficiency -induced spasms of umbilical vessels .Relation to preeclampsia, hypertension, growth retardation. Science 221: 376-378.

53. Zhang A, Cheng TP-O, Altura BM (1992) Magnesium regulates intracellular freeionized calcium concentration and cell geometry in vascular smooth muscle cells. Biochim Biophys Acta 1134: 25-29.

54. Altura BM, Altura BT (1995) Magnesium in cardiovascular biology. Sci Am Science \& Med 2(3): 28-37.

55. Delpiano M, Altura BM (1996) Modulatory effect of extracellular $\mathrm{Mg}^{2+}$ on $\mathrm{K}^{+}$and $\mathrm{Ca}^{2+}$ currents in capillary endothelial cells from rat brain. FEBS Lett 394: 335-339.

56. Delpiano M, Altura BM (1997) Transmembrane currents in capillary endothelial cells are modulated by $\mathrm{Mg}^{2+}$ ions. Adv Exp Med Biol 410: 115-118.

57. Altura BM, Zhang A, Altura BT (1997) Exposure of piglet coronary arterial muscle cells to low concentrations of $\mathrm{Mg}^{2+}$ found in blood of ischemic heart disease patients results in rapid elevation of cytosolic $\mathrm{Ca}^{2+}$ : relation to sudden infant death syndrome. Eur J Pharmacol 338: R7-R9.

58. Zhang A, Fan S-H, Cheng TP-0, Altura BT, Wong RKS, Altura BM (1996) Extracellular Mger modulates intracellular $\mathrm{Ca}^{2+}$ in acutely isolated hipocampal CA1 pyramidal cells of the guinea pig. Brain Res 728: 204-208.

59. Altura BM, Altura BT, Gebrewold A, Ising H, Gunther T (1993) Extraaural effects of chronic noise stress on blood pressure, microcirculation and electrolytes in rats: Modulation by magnesium. In: Noise and Disease, Ising H, Kruppa B, eds. Gustav Fischer Verlag, Stuttgart/New York, p 81-90.

60. Altura BM, Altura BT (1993) Kardiovaskulare risikofaktoren und Magnesium: Zusammenhange mit Arteriosklerose, ischumischer Herzkrankrankheit und Hypertonie. In: Noise and Disease, Ising H, Kruppa B, eds. Gustav Fischer Verlag, Stuttgart/New York, p 451-473.

61. De Baaj JHE, Henderop JG, Bindels RJ (2015) Magnesium in man: implications for health and disease. Physiol Rev 95:1-46.

62. Altura BM, Altura BT (1996) Magnesium as an extracellular signal in cardiovascular pathobiology. Japn J Soc Magnes Res 15: 17-32.

63. Saris NE, Mervaala E, Karppanen H, Khawaja A, Lewenstam A (2000) Magnesium : an update on physiological, clinical and analytical aspects. Clin Chim Acta 294:1-26.

64. Seelig MS, Rosanoff A (2003) The Magnesium Factor. The Penguin Group, New York.

65. Ford ES, Mokdad AH (2003) Dietary magnesium intake in a national sample of US adults. J Nutr 133: 2879-2882.

66. Mosfegh A, Goldman J, Abuja J, Rhodes D, La Comb R (2009) What We Eat in America. NHANES 2005-2006: usual Nutrient Intakes from Food and Water Compared to 1997 Dietary Reference Intakes for Vitamin D, Calcium, Phosphorus, and Magnesium. U.S. Department of Agricultural research.

67. NHANES 2009-2012 (2017) Dietary Reference Intakes for Vitamin D, Calcium, Phosphorus, and Magnesium. U.S. Department of Agricultural Research.

American Research Journal of Cardiovascular Diseases

Page 32 
Exposure to High Levels of Noise Poses Hazards and Risks for Development of Hypertension and Heart Disease: Potential Roles of Unrecognized Ionized Hypomagnesemia and Release of Ceramides and Platelet-Activating Factor

68. Altura BM, Lewenstam A (1994) Unique Magnesium -Sensitive Ion selective Electrodes. Scand J Clin Lab Invest 54(suppl 217) : 1-100.

69. Ising H (1993) Extraaural effects of chronic noise exposure in animals-A review. In: Noise and Disease, Ising H, Kruppa B,eds.Gustav Fiscaher Verlag, Stuttgart/New York p 81-90.

70. Wu F, Altura BT, Barbour RL, Altura BM (1992) Low extracellular magnesium results in cardiac failure in isolated perfused hearts. Magnes Trace Elem 10: 364-373.

71. Altura BM, Barbour RL, Dowd TL, Wu F, Altura BM, et al. (1993) Low extracellular magnesium induces intracellular free Mg deficits, ischemia, depletion of high-energy phosphates and cardiac failure in intact working rat hearts: A 31P-NMR study. Biochim Biophys Acta 1182: 328-332.

72. Wu F, Altura BT, Gao J, Barbour RL, Altura BM (1994) Ferrylmyoglobin formation induced by acute magnesium deficiency in perfused rat heart causes cardiac failure . Biochim Biophys Acta 1225: 158-164.

73. Altura BM, Carella A, Zhang A, Wu F, Altura BT (2017) Extraaural chronic noise stress results in deficits in intracellular free $\mathrm{Mg}^{2+}$, ischemia, reduction in high-energy phosphates, acidification of intracellular $\mathrm{pH}$, increased levels of inorganic phosphate, elevated levels of myocyte $\mathrm{Ca}^{2+}$ levels, and alterations in sphingolipid metabolism in hearts of Wistar rats. Submitted.

74. Merrill AH Jr, Jones DD (1990) An update of the enzymology and regulation of sphingolipid metabolism. Biochim Biophys Acta 1044: 1-12.

75. Haimovitz-Friedman A, Kolesnick RN, Fuchs Z (1997) Ceramide signaling in apoptosis. Br Med Bull 53:539-553.

76. Hannun YA, Obeid LM (2002) The ceramide - centric universe of lipid-mediated cell regulation: stress encounters of the lipid kind. J Biol Chem 277: 25847-25850.

77. Auge N, Negre-salvayre R, Levade T (2000) Sphingolipids and metabolites in vascular signal and atherosclerosis. Progr Lipid Res 39: 207-239.

78. Pandey S, Murphy RE (2007) Recent advances in the immunobiology of ceramide. Exp Med Pathol 82: 298-309.

79. Altura BM, Gebrewold A, Zheng T, Altura BT (2002) Sphingomyelinase and ceramide analogs induce vasoconstriction and leukocyte-endothelial interactions in cerebral venules in the intact rat brain: insights into the mechanisms and possible relation to brain injury and stroke. Brain Res Bull 58: 271-278.

80. Bielawska AE, Shapiro JP, Jiang L, Melkonyan HS, Piot C, et al. (1997) Ceramide is involved in triggering of cardiomyocyte apoptosis induced by ischemia and reperfusion. Am J Pathol 151: 1257-1263.

81. Getz GS (2008) The two Cs: ceramide and cardiomyopathy. J Lipid Res 49: 2077-2078.

82. Empinado HM, Deevska GM, Nokolova-Karakashian M, YooJK, Christou DD, et al. (2014) Diaphragm dysfunction in heart failure is accompanied by increases in neutral sphingomyelinases activity and ceramide. Europ J Heart Failure 16: 519-525.

83. Yu J, Pan W, Shi R, Tang T, Li Y , et al. (2015) Ceramide is upregulated and associated with mortality in patients with chronic heart failure. Canad J Cardiol 31: 357-363.

84. Morrill GA, Gupta RK, Kostellow AB, Ma GY, Zhang A, et al. (1997) $\mathrm{Mg}^{2+}$ modulates membrane lipids in vascular smooth muscle cells . FEBS Lett 408: 191-194.

85. Fruwith GO, Lodi A, Hermeiter A (2007) Oxidized phospholipids: from molecular properties to disease. Biochim Biophys Acta 1772: 718-736. 
Exposure to High Levels of Noise Poses Hazards and Risks for Development of Hypertension and Heart Disease: Potential Roles of Unrecognized Ionized Hypomagnesemia and Release of Ceramides and Platelet-Activating Factor

86. Prescott SM, Zimmerman GA, Stafforini DM, McIntyre TM (2000) Platelet-activating factor and related lipid mediators. Annu Rev Biochem 69: 419-445.

87. Montrucchio G, Alloatti G, Camussi G (2000) Role of platelet-activating factor in cardiovascular pathophysiology. Physiol Rev 80: 1669-1699.

88. Altura BM, Li W, Zhang A, Shah NC, Shah GJ, et al. (2016) The expression of platelet-activating factor is induced by low extracellular $\mathrm{Mg}^{2+}$ in aortic, cerebral and neonatal coronary vascular smooth muscle: cross-talk with ceramide production, NF-kB and proto-oncogenes: possible links to atherogenesis and sudden cardiac death in children and infants, and aging: Hypothesis, review and viewpoint. Int J Cardiol Res 3: 47-67.

Citation: M. Altura B, Gebrewold A, Carella A, C. Shah N, T. Altura B. "Exposure to High Levels of Noise Poses Hazards and Risks for Development of Hypertension and Heart Disease: Potential Roles of Unrecognized Ionized Hypomagnesemia and Release of Ceramides and Platelet-Activating Factor". American Research Journal of Cardiovascular Diseases. 1(1); pp: 25-34

Copyright (c) M. Altura B, Gebrewold A, Carella A, C. Shah N, T. Altura B. This is an open access article distributed under the Creative Commons Attribution License, which permits unrestricted use, distribution, and reproduction in any medium, provided the original work is properly cited. 